\title{
SLAAPZIEKTE IN EN ROND BWAMANDA: ACTUELE SITUATIE IN DE UBANGI-STREEK
}

\section{SEMA HURUGO}

\section{OPMARS VAN DE SLAAPZIEKTE}

De slaapziekte (Trypanosomiasis) is momenteel een zeer alarmerend gezondheidsprobleem in de Ubangi-streek, voornamelijk in de volgende districten:

- gezondheidszones van Karawa en Loko (Noord-Ubangi) - gezondheidszones van Gemena, Bwamanda en Tandala (Zuid-Ubangi) Er zouden nu eveneens enkele gevallen zijn in Yakamba, Budjala.

In 1993 werden 3.961 slaapzieken opgespoord; in 1994 bijna 6.000 , en dit met beperkte middelen.

Tabel 1: aantal mensen onderzocht door de mobiele teams (actieve screening) en door de gezondheidscentra/hospitalen (passieve screening van mensen die zich aanbieden met één of andere klacht)

\begin{tabular}{||l|l|l|l||}
\hline Gezondheidszone & Mobiele teams & $\begin{array}{l}\text { Gezondheidscen- } \\
\text { tra en hospitalen }\end{array}$ & Totaal \\
\hline GEMENA & 11.538 & 1.419 & 12.954 \\
\hline BWAMANDA & 17.514 & 1.823 & 19.337 \\
\hline KARAWA & 33.792 & 4.799 & 38.591 \\
\hline TANDALA & 44.861 & 175 & 45.036 \\
\hline BOMBOMA & 968 & 7 & 975 \\
\hline LOKO & & 167 & 167 \\
\hline TOTAAL & 108.670 & 8.390 & 117.060 \\
\hline
\end{tabular}


Tabel 2: aantal slaapzieken ontdekt in het eerste stadium (gemakkelijk te genezen en nog geen hersenaantasting) en in het tweede stadium (behandeling moeilijk en aanwezigheid van de parasiet in de hersenen).

\begin{tabular}{|l|c|c|c||}
\hline $\begin{array}{l}\text { Gezondheids- } \\
\text { zone }\end{array}$ & $1^{\circ}$ Stadium & $2^{\circ}$ Stadium & TOTAAL \\
\hline GEMENA & 199 & 1.434 & 1.635 \\
\hline BWAMANDA & 182 & 646 & 829 \\
\hline KARAWA & 412 & 2.340 & 2.812 \\
\hline TANDALA & 158 & 416 & 586 \\
\hline LOKO & 10 & 91 & 101 \\
\hline BOMBOMA & 2 & 20 & 22 \\
\hline TOTAAL & 963 & 4.947 & 5.985 \\
\hline
\end{tabular}

P.S. Het verschil tussen de som van het eerste en het tweede stadium en het totaal geeft het aantal gevallen waarvan men niet weet in welk stadium de ziekte verkeerde.

\section{ORGANISATIE VAN DE STRIJD TEGEN DE SLAAPZIEKTE}

De coördinatie en de organisatie worden verzekerd door C.D.I.-Bwamanda. Twee mobiele ploegen doen aan actieve screening; deze van Boyasebego in de dorpen van Noord-Ubangi, deze van Bwamanda in Zuid-Ubangi.

Sommige gezondheidszones hebben de detectie van slaapziekte geïntegreerd in hun andere activiteiten van diagnose en ziektebestrijding. Dit loopt niet altijd gesmeerd vanwege de specifieke competentie die vereist is om de slaapziekte op te sporen. 


\section{VOORNAAMSTE PROBLEMEN}

Met de actieve screening wordt maar een fractie van de bevolking bereikt: er zijn slechts 2 mobiele ploegen voor een te onderzoeken bevolking van ongeveer 1 miljoen.

Geregeld is er een gebrek aan de specifieke geneesmiddelen, waardoor opgespoorde slaapzieken niet onmiddellijk kunnen behandeld worden; dit ontmoedigt zowel de bevolking als het medisch personeel.

Gebrek aan logistieke steun (materiaal, wagens, benzine enz.), evenals aan de typische vallen voor de tseetseevliegen die de slaapziekte overbrengen.

Het medisch personeel in vele gezondheidscentra en ook in hospitalen hebben in het algemeen onvoldoende ervaring en competentie in verband met de opsporing, de behandeling en de opvolging van slaapzieken.

\section{SUGGESTIES VOOR EEN MEER EFFECTIEVE BESTRIJ- DING VAN DE SLAAPZIEKTE}

Een veel groter deel van de bevolking die het risico loopt besmet te worden/zijn, zou moeten regelmatig onderzocht worden. Hiervoor is de oprichting en de uitrusting van 4 nieuwe mobiele teams nodig.

De bestaande equipes en de coördinatie zijn eveneens toe aan een wagen en voldoende werkingsmiddelen.

Het verzekeren van een regelmatige bevoorrading aan geneesmiddelen; de maandelijkse noden zijn:

- Arsobal:

5.500 ampullen

- Suramine (Bayer 205):

300 flacons

- Pentamidine:

500 flacons

- DFMO of Lampit voor de resistente gevallen: ongeveer 30 zieken per maand

Een aangepaste vorming/training organiseren voor de artsen en de verplegenden. 
In belangrijke besmettingsgebieden zouden tseetsee-vallen moeten ter beschikking gesteld worden en zouden verantwoordelijken moeten opgeleid worden.

\section{BESLUIT}

Indien de opstoot van de slaapziekte-epidemie niet tot stilstand kan gebracht worden, dreigt er een regelrechte medische, sociale en economische ramp voor de hele Ubangi-streek.

Het zijn voornamelijk de middelen die ontbreken om een efficiënte bestrijding van deze plaag mogelijk te maken. De bestaande structuren van C.D.I.- Bwamanda en de bekwaamheid van zijn medisch personeel staan borg voor een doeltreffende aanwending van deze middelen teneinde de slaapziekte in gans Ubangi terug te dringen. 


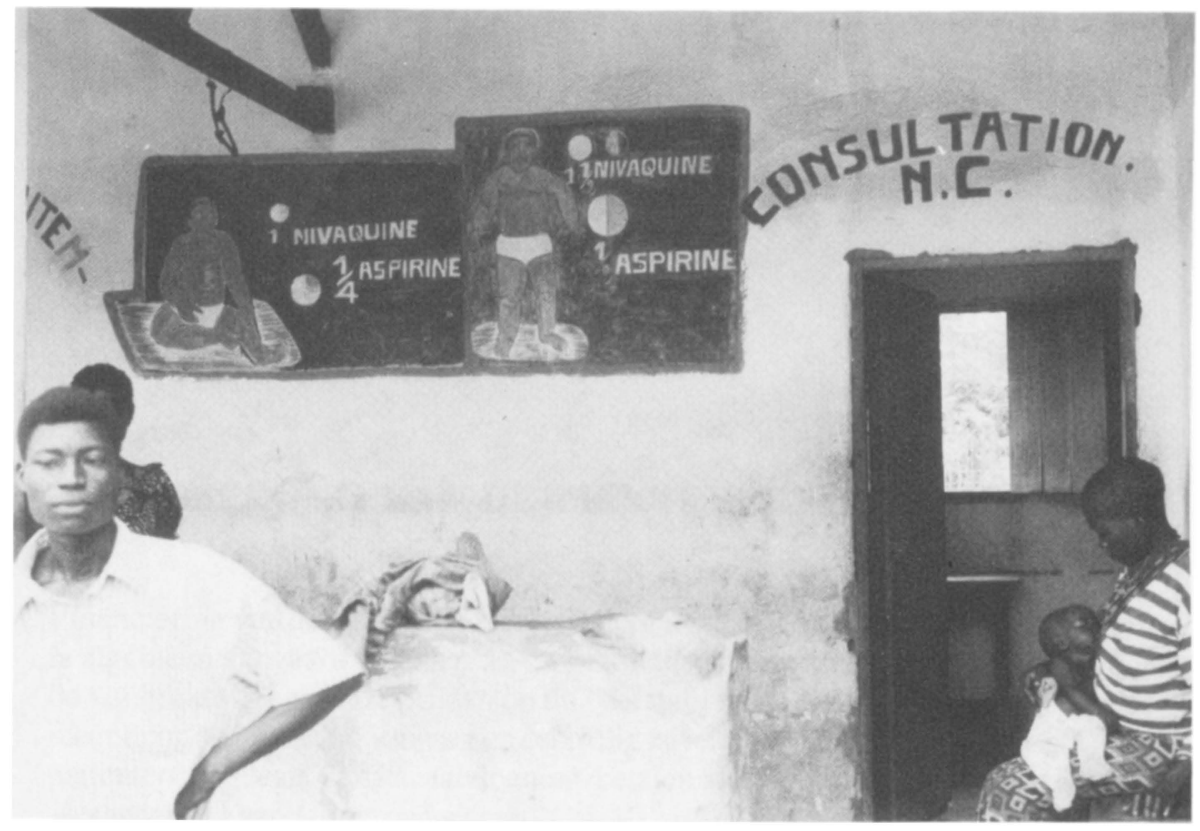

Gezondheidscentrum in de gezondheidszone van Bwamanda

Centre de Santé dans la zone de santé de Bwamanda 